Article

\title{
Science, Technology and Innovation through Entrepreneurship Education in the United Arab Emirates (UAE)
}

\author{
Irfan Hameed ${ }^{1, *}$, Muhammad Babar Khan ${ }^{1}$, Atif Shahab ${ }^{1}$, Imran Hameed ${ }^{2}$ and Faisal Qadeer ${ }^{2}$ \\ 1 Department of Business Administration, Iqra University, Karachi 75500, Pakistan; \\ babarali4u@hotmail.com (M.B.K.); atif@iqra.edu.pk (A.S.) \\ 2 Lahore Business School, The University of Lahore, Lahore 54000, Pakistan; \\ imran.hameed@lbs.uol.edu.pk (I.H.); faisal.qadeer@lbs.uol.edu.pk (F.Q.) \\ * Correspondence: irfan.h@iqra.edu.pk; Tel.: +92-333-5503036
}

Academic Editors: Muhammad Khurram Khan and Marc A. Rosen

Received: 26 September 2016; Accepted: 27 November 2016; Published: 9 December 2016

\begin{abstract}
The purpose of this study is to investigate the ways of achieving Science, Technology and Innovation (STI) in UAE. Previously, sustainability within an entrepreneurship context has been related to economic viability as opposed to sustainability in its broadest sense. Through a survey research method, we have highlighted the effects of three independent variables and two intervening variables on three important outcomes, innovation, need for achievement and motivation, which ultimately contributes towards STI. These data have been collected from the students of a well-known university in Al-Ain, UAE. The responses of 251 students have been utilized for analysis. For hypotheses testing, we used AMOS 18 (Structural Equation Modeling) and SPSS 20. The study revealed that all of the predictors have a strong effect on the outcome variables, which leads to STI in UAE. There is a strong need to revise the curriculum of higher education institutions of UAE to develop self-confidence, locus of control and risk taking propensity among students. The study provides novel insight into entrepreneurship education and serves as an initial benchmark in the field.
\end{abstract}

Keywords: sustainability; entrepreneurship; science; technology and innovation

\section{Introduction}

It is essential for a nation to remain competitive in today's globalized era. Investment in science, technology and innovation (STI) can be a viable means of achieving this target. Even at a micro level, innovation leads a firm to create competencies, which are difficult to imitate and hence prove helpful in attaining a firms' competitive advantage [1]. Firms must be encouraged to innovate, which will ultimately lead to increased innovation and sustainable development of the whole nation [2]. Advancement in terms of STI can be achieved by investing in entrepreneurial development and training, which can be provided in universities. Reports suggest that The United Nation's millennium development goals can be achieved through STI [3]. These goals include poverty elevation, and sustainability in terms of environment and education for everyone. It can be noticed that STI is a vital topic under discussion and is a part of the global mission for sustainable development.

In, The United Arab Emirates (UAE), STI is considered as a new driver for the economy. In developed countries, such as France, $50 \%$ of the new firms are based on technology [4]. UAE is trying hard to have technological arrangements with the West and Asia with the goal of diversifying its income and economy. Resultantly, Advanced Technology Company and the Mubadala Development Company along with others are created [5]. Abu Dhabi by Masdars initiative is creating an environment for innovation, by attracting global research minds. Masdar is a subsidiary of Mubadala, with the goal of making Abu Dhabi the world's first carbon free city by focusing on sustainable and renewable 
energy [6]. Dubai Silicon Oasis initiative, on the other hand, is an attempt to make Dubai the center for electronic R\&D and Innovation.

Minister of Education and Scientific Research (Sheikh Nahyan Bin Mubarak) pointed out that funding of scientific research is weak in UAE [7]. Some initiatives like creation of The National Research Foundation have been taken. The human capital with desired skills is still lacking. Hence, there is a strong need to create individuals with entrepreneurial drive to start innovative business enterprises.

Technology and the technology driven new firms' development must be encouraged in the knowledge economy. Innovation and technology are considered as the means of increasing exports and achieving goals in less knowledge oriented economies like UAE. Using data from 2011, UAE Global Entrepreneurship Monitor (GEM) Report [8] has found that almost all new businesses started in UAE in 2011 operate in sectors with no or low technological levels, with only $2.3 \%$ being medium-tech or high-tech new ventures. In 2006, no or low technology oriented ventures in UAE were $97 \%$ of the total ventures and medium or high technology ventures were only $3 \%$. Over a period of six years (2006-2011), there is no increase in medium or high technology oriented ventures; in fact, there is a slight decrease from $2006(3 \%)$ to 2011 (2.3\%). The percentages are even less in the years between 2006 and 2011 (Figure 1).

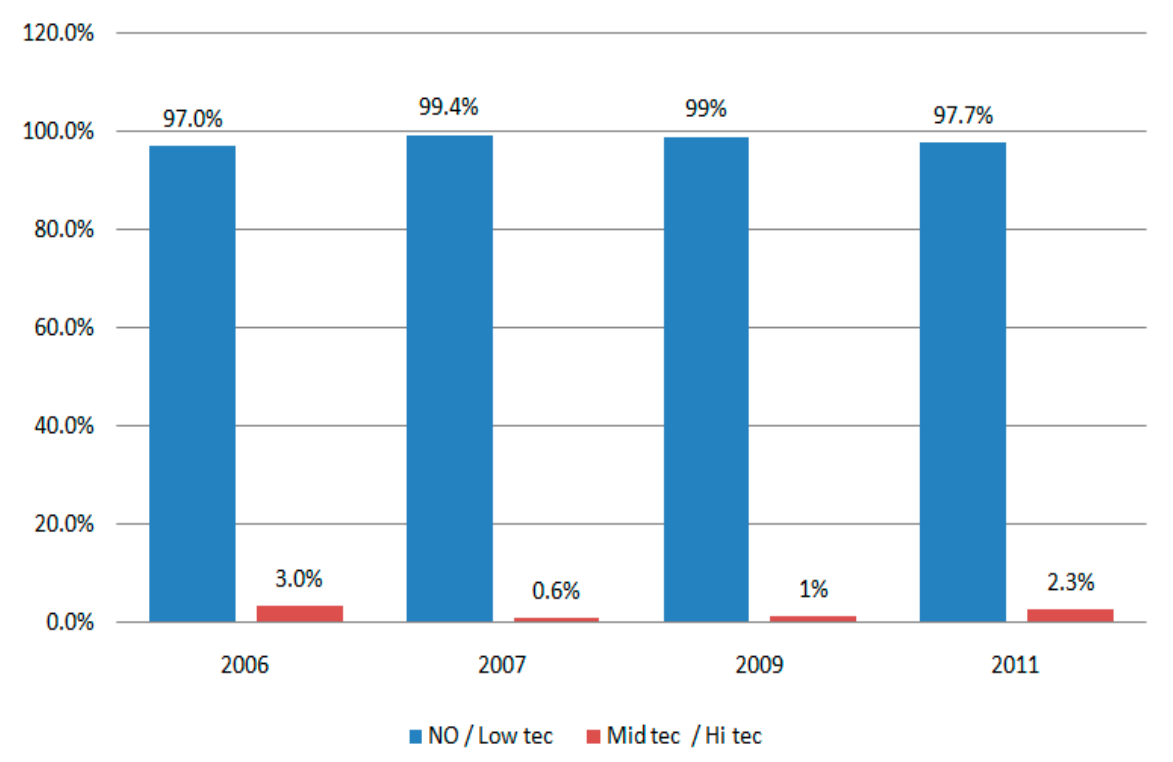

Figure 1. Level of technology sector early stage entrepreneurs [8].

A similar situation exists amongst established entrepreneurs that have owned and operated a business for longer than three years (Figure 2). In comparison to the average of the innovation driven economies $(7.7 \%)$ surveyed in 2011, UAE is much lower in terms of the share of medium to high technology sector (only $2.4 \%$ ). This share for highest ranked country, Norway, is $14.3 \%$, i.e., about six times more than UAE. Figure 2 explains that the established firms' percentages for no or low technology orientated ventures accounts for $98.3 \%$ of tall established businesses. Over the period of six years (2006-2011), there is a minute increase, as in 2011 the percentages for medium or high technology oriented established ventures are $2.4 \%$ with an increase of $0.7 \%$ from 2006 , which is again very low compared to most of the advanced nations. 


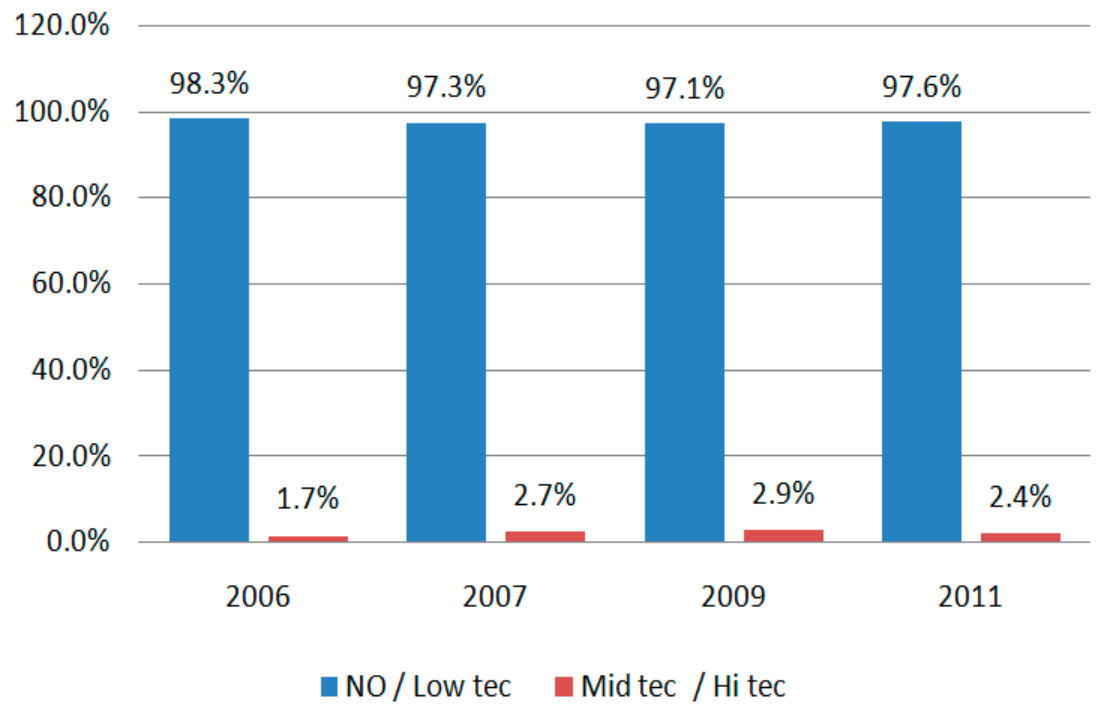

Figure 2. Level of technology sector established entrepreneurs [8].

Entrepreneurship education in terms of its effectiveness and its success factors has been the focus of several studies $[9,10]$. With changes in technology and globalization, entrepreneurship education is now a vital skill that helps graduates earn their livelihood by establishing their own business. New business startups based on innovative ideas lead to sustainable growth. Due to its ever increasing importance, entrepreneurship education becomes a mandatory part of university education. Entrepreneurship education develops creativity, innovation and risk taking, as well as the ability to plan and manage business towards set objectives.

Entrepreneurship Education Program (EEP) is aimed at fostering entrepreneurship values and encouraging the spirit of self-reliance and entrepreneurial culture among graduates, in which students will be trained to explore opportunities, become creative and innovative, hence they will understand related aspects of business, market, risk, and competition [11].

EEP is important in producing entrepreneurs who have all the necessary knowledge and skills in conducting a business [12]. Often supported by government policy, formal EEP is sometimes made a mandatory program in higher learning institutions in countries such as Canada [13], Singapore [14], UAE [15], Turkey [16], the Netherlands [17] and Germany [18]. Even so, a contradictory view of the role of EEP was argued [18], whereby education and exposure on the actual entrepreneurship experience were seen to supersede indoctrination.

EEP can either be elective or mandatory; in terms of contents, it usually includes both theoretical and practical elements. For instance, UK's Quality Assurance Agency (QAA) requires the exposure of extra-curricular opportunities through marketing, student engagement and communication [19]. Teaching and learning normally comprises lectures and tutorials, with preferences for involvements by real-life entrepreneurs [18]. However, the objective and structure of EEP may differ in countries, depending on various factors including country's history, prevailing policies, development level and economic systems.

This study focuses on three research questions for further argumentation and formulation of hypotheses: (a) How does entrepreneurship education lead to science, technology and innovation? (b) What characteristics are inculcated in university students by entrepreneurship education? (c) Why is entrepreneurship education required for sustainable development of UAE? Before moving on to review of entrepreneurship theory and formal hypotheses grounding, let us briefly explore UAE context, because the present understanding of entrepreneurship education and its links to STI is limited to developed countries. 


\section{UAE and Entrepreneurship Education}

UAE is a federation of seven states, commonly known as "Emirates". The state of UAE came into being on 2 December 1971 [20]. About 40 years ago, it was one of the least developed nations with an economy mainly based on nomadic animal farming, fishing, extraction of pearls, etc. Oil exploration triggered its economic development. Moreover, the political and economic stability played an amplifying role for attracting investments in UAE [21].

In 2006, under the mandate from the highest authorities of UAE, the Abu Dhabi Council for Economic Development and the Department of Planning and Economy initiated development of a long term economic vision 2030 for UAE. The expected outcome was to strategize UAE to cater to key enablers of economic growth. The vision aligned the key activities including empowerment of private sector which supported entrepreneurship and the new businesses risk-taking [20]. The vision aimed at reversing the dependence on oil and gas dominated GDP, from 59\% in 2005 to $36 \%$ in 2030, and inclination towards small and medium enterprises (SMEs) and other businesses rather than only oil pumping and marketing [20].

Keeping in view that SMEs contribution to GDP of any country is $30 \%$ and accounts for $86 \%$ of employment [21], UAE now stimulates nationals to go for new startups rather than working for someone else. UAE is supporting entrepreneurship because the government has realized that it is the fundamental source of economic development and changing the overall settings of economy [20,22-24]. Eventually, the policy makers have shifted their focus to support such activities which are innovation oriented. Khalifa Fund and The Mohammed Bin Rashid Establishment are formed for young entrepreneurs to become part of the socio economic development. These activities are now shifting the focus of youth towards knowledge-based activities leading towards innovation and entrepreneurship.

UAE government's vision 2030 is precise but one thing is hampering the growth of economy: public schools (primary and secondary) education does not support this vision. Schools are unable to inculcate the entrepreneurial skills such as innovation and creativity among the students [25-27]. The situation becomes perilous when banks show low concern to finance SMEs, and, even though financial support from the financial institutions is essential to raise entrepreneurial culture and attitude in masses [28], fewer banks support new businesses [29].

The recent fluctuations in oil and gas prices made Gulf Cooperation Countries (GCC) including UAE consider investing in human capital and promote technology and innovation. For this purpose, a business oriented environment is required having the snarl of venture capital, financing mechanism and transparent regulation. For capitalizing on human capital, it was integral for UAE to transform its education dogma. They made investment at all levels of education and made it necessary to implement research and innovation at all levels because education aids knowledge-based sustainable productive economies and encourages young entrepreneurs to start new ventures and innovative ideas.

The after effects were anticipative [30], which reflected that the total early stage entrepreneurial activity at UAE is at par with other developed economies such as Singapore and Norway. The government was determined to influence the minds of young individuals to get motivated towards entrepreneurship. The major pillar was education and its integration at school, college and university level. Support at all levels was provided to universities for short term entrepreneurial activities. Students were incentivized and exposure was given by providing them travelling opportunities to developed countries. Business plan competitions were conducted at universities to inculcate entrepreneurial spirit into students. Media, family support and role models also varnished young individuals to become entrepreneurs.

Moreover, in GCC inclusive of UAE, educational reforms are proposed by different authors who are engrossed towards research, innovation and technology intended to relate management practices and strategies to transfer broad range of solutions. Ali M. Al-Khouri [31] derived some reforms from Europe and proposed benefits from digital age by conducting business online, introducing information communication and technologies (ICT) in service industry, improving research innovation through ICT, and empowering digital skills and benefit of ICT to society. 


\subsection{Entrepreneurship Education and Cultural Barriers in $U A E$}

Cultural aspect of collectivism versus individualism is usually observed as a most meaningful aspect to study culture's favorableness for the development of entrepreneurial intentions [32]. UAE's culture is collectivist where people use to live in a strong united society and throughout their life they have a concrete loyalty [33]. Entrepreneurial research suggests that individualist cultures produce more entrepreneurs than collectivist. A balance between both collectivism and individualism helps to provide a more appropriate setting to produce entrepreneurs [34]. There has been an increasing interest in knowing how entrepreneurship helps enhance organizational productivity and efficiency [35]. In Arabian higher education, students do not readily accept entrepreneurship due to their collectivist culture, their educational background and lack of formal entrepreneurial education provided to them compared to USA and European business students.

The graduate entrepreneurship report of national council finds that the graduates having formal entrepreneurial education tend to demonstrate more entrepreneurial intentions lead towards novelty. It helps to modify the business trends and add value to contemporary competitive global business settings [36]. Though the higher education system of UAE still needs to focus on many areas for quality academics [37], it is one of the best education systems in the whole GCC [38,39].

A longitudinal study finds that entrepreneurial actions are predicted by entrepreneurial intentions [40]. Therefore, it is highly relevant for educators, practitioners and policy makers to identify what influence entrepreneurial intentions. Policy makers, practitioners and academicians should amplify their efforts to farm the entrepreneurial approach in society [41]. Research highlighted the importance of entrepreneurship education and suggested to make it a part of studies at schools, institutions, universities and training programs levels [42]. Growth of this education has also been claimed in countries such as Malaysia since the start of this program from mid 1990s [43-45]. Therefore, most universities, even in GCC countries, and at international level are offering this program since inception. Moreover, the recent development in global business arena entrepreneurship education emphasizes progressive and experiential learning methods [46].

Most developed countries are investing drastically in entrepreneurial education at universities [47], high schools [48] and even in primary schools [49]. Harvard University started this in 1945 to stimulate the economic condition of USA [50], now it is taught in Europe through four channels: (a) As a course, as an entirely separate subject, or with a theoretical focus, learning how to startup a business; (b) as a supplementary subject; (c) as main topic which focused on developing the innovative, confidence and initiative skills; and (d) as an informal academic course.

Many authors highlight the importance of Entrepreneurship, for example it was proposed [51] that for the sake of national revolution, entrepreneurship is a lifeline to transform any country from middle income to high income economy by 2020. This is why it is imperative for the practitioners, teachers, educators and policy makers to preach this concept within the society [41]. Thus, universities should aim to teach the entrepreneurship course at bachelor and master's levels. The University Utara Malaysia has developed a concentrated segment, which has offered the teaching and research facility of entrepreneurial concept since 2004 [52-54].

As discussed above, there has been a thorough shift in the last two decades in how societies and businesses function as growth in ICT have changed the way people live, and access to information has become more important. For the development of potential entrepreneurs and more business opportunities, ICT and infrastructure have become vital ingredients $[55,56]$. Although in the whole Middle East, UAE has the most advanced markets, the telecommunication sector is least liberalized, having no competition and entry of foreign investment. Remarkably, UAE ranks 31st in ICT infrastructure; per capita GPD of UAE is higher than many advanced economies, even USA; across the 54 Global Entrepreneurship Monitor (GEM) countries, UAE has the 6th highest business start-up expectations rate, as $43 \%$ of populace are thinking about starting businesses in the next three years [57]; and it is among the 20 wealthiest nations. To fully tap this immense potential, UAE needs to focus on transforming their economy into a knowledge-based economy. 
The transformation from oil based economy to the knowledge based economy has a strong rational at the back end, the recent plunge and fluctuation in oil prices is one main reason to justify this diversification. Moreover, to expedite this process of transformation, UAE should invest more in social and physical infrastructure such as schools and health services. It is entrepreneurship education that correlates economic growth and human capital development, i.e., the knowledge-based economy. This way, UAE will see more economic growth, multilevel governance will become easier, knowledge infrastructure such as universities and consultancies will flourish, and community and culture will become more sustainable.

\subsection{Skills Development through Entrepreneurial Education}

Education is the strongest ingredient of the entrepreneur's success [58] and authors [59,60] are in favor of formal teaching and learning of entrepreneurship to students. Simultaneously, education of consumers and employees also affect entrepreneurs' venture productivity [61]. Higher income is eventually the proof of success, which derives from higher productivity backed by human capital developed through education $[62,63]$. With an educated work force, we expect more innovations, high productivity and strengthening of economy [64]. In a nutshell, entrepreneurial education leads to positive intentions of entrepreneurship. Attitudes, perceived behavioral control and norms are the drivers of entrepreneurship intentions [65]. Entrepreneurial education shape up and influence these fundamentals [66].

Among formal and informal education for entrepreneurship, there are some contradictory findings to become an actual entrepreneur. Syahrina et al. [60] support the finding of Collins et al. [59]; that is, among all graduates produced by higher education institutions provided with formal entrepreneurial education, increase in production quantity of entrepreneurs is satisfactory. Formal entrepreneurial education supports to enhance the production of entrepreneur graduates, reduces unemployment and boosts the economy of region [67]. It encourages graduates to transform into job creators instead of job seekers. On the other hand, Abidin et al. [68] suggest that informal education is more effective to arouse entrepreneurial activities and influence graduates towards entrepreneurial intentions. It is based on self-determining and personal experiences, which shapes an ordinary individual into an extraordinary entrepreneur [69]. Family business is the most suitable example of informal entrepreneur education, where every individual gets the experience from an environment based on self-determining and personal experiences. Thus, both formal and informal entrepreneurship education can transform graduates into entrepreneurs.

\section{Theory and Hypotheses}

\subsection{Entrepreneurship Theories}

James Truslow Adams [70] proposed that "life should be better and richer and fuller for everyone, with opportunity for each according to ability or achievement". Building on this dream, Schumpeter [71] articulated the Theory of Innovation, suggesting that entrepreneurs have the desires to create their own kingdom, and gain joy from creating something new. Entrepreneurship is all about "creative destruction". He linked his theory of innovation with economic development theory and proposed that it comes from the development of historical events of structural change of innovation and it has five aspects: new product development, new method application, new market opening, new sources acquisition and proposition of new industry. This theory of Innovation provides the backbone to basic conception of entrepreneurship.

We argue that inculcating such characteristics into students through entrepreneurship education will lead to sustainable startups. Other than the characteristics proposed by Schumpeter [71], an entrepreneur should also have an internal drive to meet his objectives called motivation. Learned Need Theory [72] suggests that, regardless of age, gender or culture, we have three motivation drivers, achievement, affiliation and power. New startups always involve risk, so it is proposed that 
an entrepreneur should have achievement as motivation because it involves risk and challenges to accomplishment what others feels challenging, but his risk must be calculated and have the backup of analysis and certainty. Affiliation is an internal drive which pushes humans to be praised by others; collaboration is also one of the appeals that energize individuals to be motivated. Therefore, it is proposed that an entrepreneur should have the motivation of affiliation because it enables him to make a strong collaboration to create something new.

Another aspect of the learned need theory is to focus on power as motivation, it suggests that power is the individual characteristics where she/he loves to win and enjoy competition. The theory proposes that the power is of two different types; individual, where people want to direct others and institutional, where people want to organize others. It has been recommended that an entrepreneur should have the power as motivation if used positively he can form teams and accomplish challenges in more effective way. In line with learned need theory, we argue that entrepreneurship education can align the motivations of individuals to achieve and accomplish risky situation, by using individual and institutional power and get praised by society as whole.

Along with McClelland [72], other authors [73,74] also suggested that success is gauged by achievement; it is also distinguished as failure prevention. People who seek achievement as motivation love difficult task to accomplish, perform difficult tasks more effectively and strike to improve onto their skill set. They take success as personal responsibility. The achievement motivation theory augments the basic instinct of an entrepreneur, by the effective entrepreneurship curriculum; this instinct of individuals may be channelized towards making them successful businessmen.

Having these basic theories of entrepreneurship and proposed characteristics of entrepreneurs, the buzz word "Sustainable Entrepreneurship" seems to a combination of theory of entrepreneurship and theory of environmental and welfare economics [75]. It is imperative for a sustainable development that education continues to add on to existing knowledge as it is a continuous process which can never be capped, if we are to evolve entrepreneurship education, empower the masses by inculcating a sense of sustainable development in their personal lives. Thus, in return it leads to the sustainable development of country and nation at large.

\subsection{Hypotheses Development}

\subsubsection{Entrepreneurship Education}

As mentioned above, entrepreneurship education is the strongest ingredient of the entrepreneur's success. Simultaneously, education of consumers' and employees' also affect entrepreneurs' venture productivity. The current study models three dependent variables that are expected to result from entrepreneurship education.

Firstly, innovativeness is a creation of a new idea or new product, or invention of a new market, in terms of entrepreneur organizing a new source of supply, or to create a new business. With innovativeness, an entrepreneur can make his way to identify a market, choosing their product and all other important procedures. Their new ideas make them a better, effective, successful entrepreneur. Innovativeness, as part of an entrepreneur's personality, is the major tool that changes individual from manger to entrepreneur [76].

Secondly, need for achievement is a forward motion that invigorates an individual to persist for accomplishment and excellence. Individuals who desperately have a need of something (which could be anything) work hard in order to fulfill that need. If an individual had a problem that needs to be solved, he would force himself to solve that problem. Need for achievement in any case brings new ways to solve a thing, and generate new ideas. Research shows a strong relationship between need for achievement and entrepreneur. This is regarded as a compulsory characteristic of entrepreneur's personality [77].

Finally, motivation leads an individual to an action or it leads a person to act in a particular way. It is an inner feeling of one self. Many researchers proposed different theories about motivation where 
motivation is categorized. Intrinsic motivation is derived from inner satisfaction and internal forces, whereas extrinsic motivation from that of external rewards. In entrepreneur, motivation should be a part of their personality; it leads them toward hard work, towards more effort, and increases their efficiency $[78,79]$.

\subsubsection{Self-Confidence as Predictor and Mediating Role of Positive Attitude}

The very first step towards the entrepreneurial behaviors starts off from the cradle and parents should motivate children to improve their self-confidence [73]. Entrepreneurship education attempts to inculcate the ability to apply theory to practice so that students gain self-confidence. It is an academic motive that increases the self-efficacy of performing a certain action [71]. Self-confidence not only enhances learning capabilities [80] of students but also affects their achievements throughout their academic career [81]. Even though entrepreneurship education has been taught in schools throughout the globe, the impact of self-confidence through entrepreneurship education is yet to be fully investigated. Once successfully inculcated through building a positive attitude, self-confidence may continue to impact incumbent's performance in practical life.

Attitude is the permanent aspect of individual's organization of motivational, emotional, perceptual, and cognitive evaluations [82]. Sociologists defines attitude as the specific reaction in a specific condition $[83,84]$. Attitudes are observed to be more dynamic and persistent to change as compare to personality traits. This attitude also exists generally and specifically regarding many objects because attitude is evaluation [85-87]. Studies show that positive attitude is an important attribute in the personality of an entrepreneur. People with positive attitude find themselves in comfort under different situations [88].

Positive attitude exists as an intermediate stage between self-confidence created through entrepreneurship educations and its outcomes. Self-confidence gained through entrepreneurship educations directly influences the affective, cognitive and behavioral components of the attitudes of students; in other words, it changes their hearts, minds and actions. When good thinking is taught as "critical thinking", as a competency applicable on teaching and learning context [89], positive attitude is learned. The core of the concept is that the entrepreneurship education instills the critical thinking in students. Now, let us see how positive attitude translates to the three dependent variables in our model.

Because critical thinkers have problem solving skills, can design systems and processes, think independently and have flexible nature to adjust into any environment [90]. Therefore, positive attitude gained through self-confidence would likely make the entrepreneur become a more creative and out-of-the-box thinker, and learn how to accomplish tasks in teams, i.e., building her/his innovativeness.

Learned need theory argues that needs are shaped up by experiences and achievement is one of the learned need which acts like and impulsion for creative destruction [71]. A positive attitude generated by self-confidence helps flourish the vigor for accomplishment and excellence, making one hardworking in his or her action to fulfill problem solving needs, or at least brings new ways to solve a problem, and generate new ideas, i.e., positive attitude improves one's need for achievement.

Positive attitude stemming from the self-confidence makes the trainee remain persistent and keep on exerting effort with full intensity because she/he feels confident for the expected external rewards and inner satisfaction from the sense of achievement due to a forcible success in the venture. This is similar to how the reward and praise from elders groom independent actions of children in their early stages of childhood, which, in turn leads towards convergence, more and new usages of existing products [71]. This is why some businesses can be enhanced if entrepreneurship education is provided to students [91]. Therefore, positive attitude directly impacts the motivation.

Overall, based on the above arguments, self-confidence gained by students through entrepreneurship education builds their positive attitude, making them more likely to try to attain news skills (e.g., innovation, need for achievement, and motivation). Thus, we expect that: 
H1a: Positive attitude mediates the positive effect of self-confidence on innovativeness.

H1b: Positive attitude mediates the positive effect of self-confidence on need for achievement.

H1c: Positive attitude mediates the positive effect of self-confidence on motivation.

\subsubsection{Locus of Control as a Predictor}

Locus of control is an individual's belief about his ability to control events and their tendency to attribute the causes of successes or failures to either themselves (internals) or external sources, such as specific situations, other people, or fate (externals) [92]. The internals are more likely to believe that they control the outcomes of their efforts and to act on their intentions [93,94]. Entrepreneurs are internals because they have the capability of controlling the events of their lives. Entrepreneurship education utilizes tools like cognitive behavioral therapy (CBT) to increase the self-efficacy or internal locus of control of the students and to improve their personal perspectives, mood, and daily functioning [95].

Paradigms that are associated with the locus of control to the CBT strategies may involve the change in the behavior of the student to increase the incumbent's ability to start something new and be a positive individual with respect to his behavior [96]. Thus, internals are more likely to create new ideas or products, or to invent a new market. In other words, internals tend to exhibit innovativeness. Research suggests that internals are likely to exhibit greater intrinsic motivation, i.e., be more achievement oriented $[94,97]$. Therefore, we can expect that:

H2a: Internal locus of control has a significantly positive impact on innovativeness.

$\mathrm{H} 2 \mathrm{~b}$ : Internal locus of control has a significantly positive impact on need for achievement.

H2c: Internal locus of control has a significantly positive impact on motivation.

\subsubsection{Risk Taking Propensity as Predictor}

Risk taking propensity is described as the intensity to bare the risk, or an individual's ability to take chances with reference to its loss. During academics, graduates are taught to be entrepreneurs, and it is an integral part of entrepreneur's career to take risk. Risk taking propensity is a distinguishing variable between and entrepreneur and a corporate manager. The only thing that discriminates an employee from an entrepreneur is the improbability or uncertainty and the risk taken by former [98,99]. Moreover, uncertainty includes the uncertain environment in which entrepreneur takes risk related to finance, career, family relations, and emotional and psychic wellbeing [100-102].

The common theme around which entrepreneurship revolves is the risk taking tendency of a successful entrepreneur. It is not just financial risk that may hinder entrepreneurial activity but also risks such as family relations and psychological wellbeing [103]. Therefore, entrepreneurship education is necessary for being successful business person because it makes you learn the capability of analysis to avoid such risks involved in starting a new venture.

Risk taking tendency among entrepreneurs creates room for experimentation with new products, services and markets, thereby making then innovative. High need achievers tend to take risk at moderate level [72]; therefore, risk taking propensity in an entrepreneur can be an intrinsic value that satisfies the desire of gain [71]. By combing these arguments, we suggest that:

H3a: Risk taking propensity has a significantly positive impact on innovativeness.

H3b: Risk taking propensity has a significantly positive impact on need for achievement.

H3c: Risk taking propensity has a significantly positive impact on motivation.

\subsubsection{Moderating Role of Fortitude}

Fortitude is the reaction and expression of a person's patience level in different scenarios [78], for example, when facing hurdles and bad situation. It was theorized by Strümpher [104] in psychological coping, emotional stability and stress tolerance. No entrepreneurial ventures start off without setbacks or un-rest, therefore, entrepreneurs use this inner ability called teamster to seek culmination and acceptability in the market. Because entrepreneurs are always willing to create something new, they 
exhibit a unique set of personality characteristics such as fortitude, inspiration, self-confidence and direct action courage.

We have grounded three antecedents of motivation, i.e., self-confidence, internal locus of control and risk taking propensity ( $\mathrm{H} 1 \mathrm{c}, \mathrm{H} 2 \mathrm{c}$ and $\mathrm{H} 3 \mathrm{c}$, respectively). Entrepreneurs may vary in their levels of fortitude; therefore, these levels of fortitude are likely to have contingent roles in the three linear relationships. Thus, we can say that the capacity of fortitude inculcated through entrepreneurship education along with the three antecedents is expected to have a combined effect.

Previous research also suggested that a person with low fortitude would be more prone to self-doubt, impaired perception of personal competency in coping with stressors and a disengagement from active coping efforts. On the contrary, a person with high fortitude would be more confident and would adopt more problem-focused styles of coping [105]. Therefore, we can suggest that when an entrepreneur has high fortitude, the impacts of self-confidence, internal locus of control and risk taking propensity on his motivation are likely to be greater than when he has low fortitude. Thus, we propose that:

H4a: Fortitude moderates the positive effect of self-confidence on motivation.

H4b: Fortitude moderates the positive effect of internal locus of control on motivation.

H4c: Fortitude moderates the positive effect of risk taking propensity on motivation.

The hypothesized model based on all hypotheses grounded in the proceeding section is shown in Figure 3.

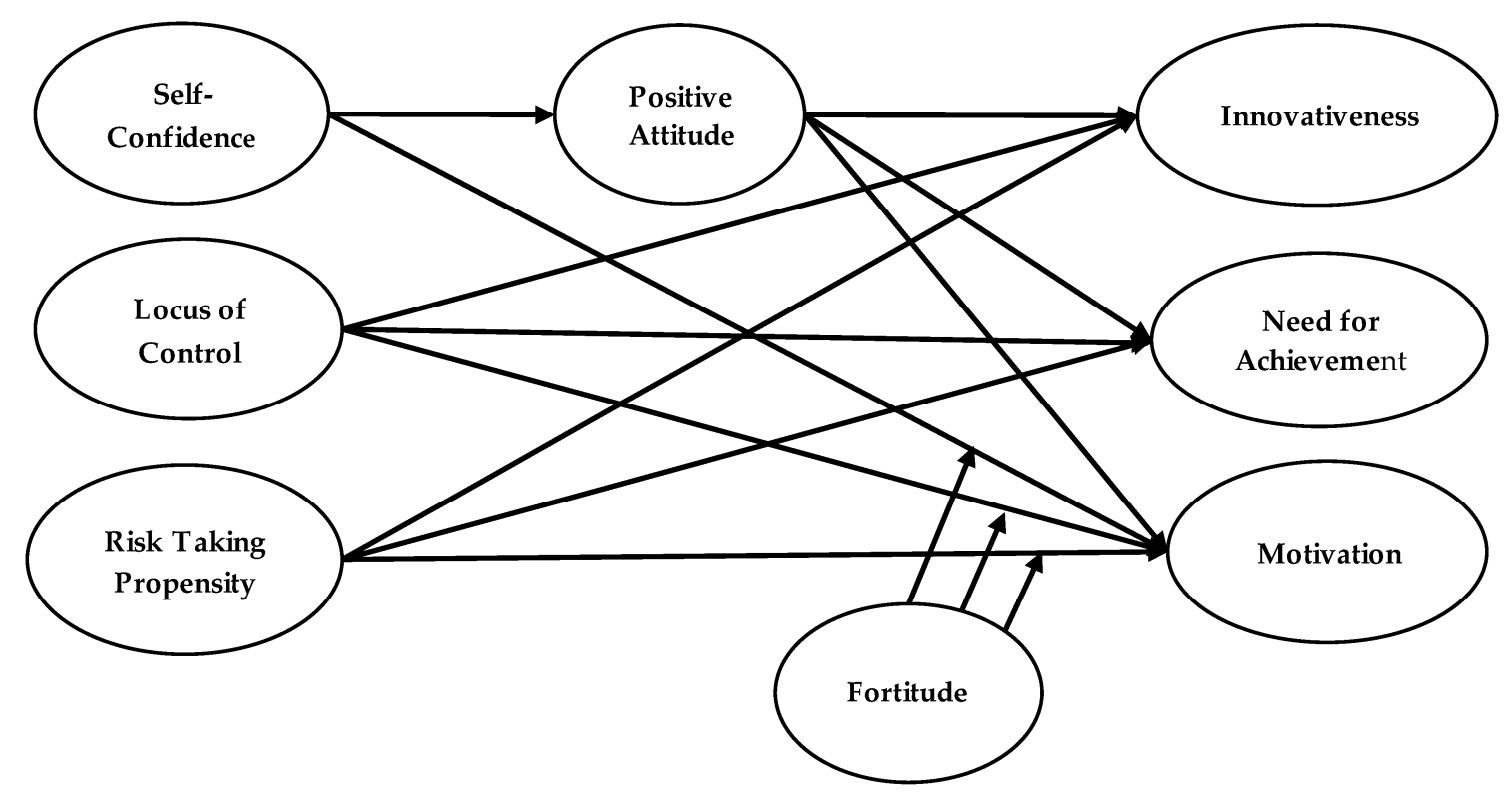

Figure 3. Hypothesized Model.

\section{Research Methodology}

\subsection{Participants}

The students (pursuing graduate and undergraduate degrees in their second last and last semester) at a university Al-Ain, UAE are the target population of the study. We randomly selected classes (as clusters), with due permission of the faculty, and we contacted them during their classes to ensure their seriousness. However, they were free to give answers or not. A self-administered questionnaire was administered and those opting to respond had to answer all survey questions. The anonymity of respondents was ensured by accompanying the questionnaire with a cover letter which explained the purpose of the research and they were asked not to reveal their names or IDs. These steps are also in 
accordance with the guidelines of Podaskoff et al. [106] for reducing the threat of common method bias in the data.

Of the distributed 300 questionnaires, the final useable responses of 251 students have been utilized for analysis. The majority of the respondents were males $(78.9 \%)$. The average age of the respondents was 22 years, only $8 \%$ were 25 or above. Most respondents $(77.7 \%)$ were full time students and the others were doing jobs or running their own businesses. When asked about their career orientation, $62.5 \%$ were inclined towards job, while $37.5 \%$ had plan to start up their own business in near future. Inclinations of males to start a new business was much higher $(42.4 \%)$ than that of women $(16.9 \%)$.

\subsection{Measurements}

All items of the study variables were rated on a 7-point Likert scale. Self-confidence was measured using the 4-item scale developed by Rosenberg [107], and a sample item is "I take a positive attitude toward myself". Internal locus of control was measured using Rotter's 4-item scale [92], and a sample item is "One should always be willing to admit mistakes". Risk taking propensity was measured using the 4-item scale of Jackson [108], and a sample item is "I generally prefer stimulation to security". Positive attitude was measured using the 4-item scale of Lam and Klockaras [109], and a sample item is "I use every opportunity to learn". Innovativeness was measured using a 4-item scale of Hurt, Joseph and Cook [110], and a sample item includes "I always investigate new possibilities". Need for achievement was measured using the 5-item scale of Hermans [111], and a sample item includes "I am good at making small steps to complete big goals". Motivation level was measured using the 5-item scale developed by Pintrich and DeGroot [112], and a sample item is "I love to do interesting and varying tasks and duties". Fortitude, the moderator, was measured using the 4 -item scale of Pretorius [105], and a sample item is "I make good use of my opportunities". Participants reported information related to their demographics in the last section.

\subsection{Statistical Test}

Missing values were replaced by using series mean. No aberrant values, i.e., values that are out of range (less than 0 or above 7) were found in the data. Cronbach's Alpha for all variables was greater than 0.70 , which means that the data are reliable.

\subsection{Hypotheses Testing}

Structural Equation Modeling (Amos 18) has been used to test Hypotheses 2a-c, and 3a-c and SPSS 20 (IBM Corp: Armonk, NY, USA, 2011) has been used for the analysis of H1a-c and H4a-c. In below mentioned tables, short forms of the variables have been used. Where inn stands for Innovation, NFA for Need For Achievement, Mot for Motivation, LC for Locus of Control, RTP for Risk Taking Propensity, PA for Positive Attitude, For for Fortitude, SC for Self Confidence.

Coefficient of Correlation is 0.329 , which states that self-confidence and positive attitude have a weak relationship with innovativeness. Coefficient of determination is 0.108 , which means that $10.8 \%$ of the model is explained by independent variables (Table 1, Model I).

Table 1. Model Summary (Testing Hypothesis H1a-c).

\begin{tabular}{cccccccc}
\hline & R & R-seq & MSE & F & df1 & df2 & $p$ \\
\hline Model I & 0.329 & 0.108 & 0.474 & 14.950 & 2 & 247 & 0.000 \\
Model II & 0.471 & 0.221 & 0.437 & 35.112 & 2 & 247 & 0.000 \\
Model III & 0.522 & 0.272 & 0.344 & 46.212 & 2 & 247 & 0.000 \\
\hline
\end{tabular}


In the first case, the significance value is 0.104 , which is more than 0.05 so there is no relationship between positive attitude and innovativeness. In the second case, the significance value is 0.000 , so there is a relationship between self-confidence and innovativeness (Table 2, Model I).

Table 2. Model (Testing Hypothesis H1a-c).

\begin{tabular}{cccccccc}
\hline \multirow{3}{*}{ Model I } & Coeff & Se & T & $p$ & LLCI & ULCI \\
\hline \multirow{3}{*}{ Model II } & Constant & 3.898 & 0.387 & 10.079 & 0.000 & 3.137 & 4.660 \\
& PA & 0.103 & 0.063 & 01.631 & 0.104 & -0.021 & 0.228 \\
& SC & 0.250 & 0.065 & 03.852 & 0.000 & 0.122 & 0.378 \\
\hline \multirow{3}{*}{ Model III } & Constant & 2.754 & 0.372 & 7.413 & 0.000 & 2.022 & 3.486 \\
& PA & 0.116 & 0.061 & 1.911 & 0.057 & -0.004 & 0.236 \\
& SC & 0.394 & 0.062 & 6.319 & 0.000 & 0.271 & 0.516 \\
\hline & Constant & 2.680 & 0.330 & 8.128 & 0.000 & 2.030 & 3.329 \\
& PA & 0.262 & 0.054 & 4.866 & 0.000 & 0.156 & 0.369 \\
& SC & 0.279 & 0.055 & 5.056 & 0.000 & 0.171 & 0.388 \\
\hline
\end{tabular}

The hypothesis positive attitude mediates the positive relationship between self-confidence and innovativeness has been rejected. Because the lower limit of confidence interval is -0.003 and the upper limit of confidence interval is $\mathbf{0 . 1 1 4}$, zero lies between the upper and lower limit of confidence interval (Table 3, Model I).

Table 3. Indirect effect of X on Y (Testing Hypothesis H1a-c).

\begin{tabular}{cccccc}
\hline & & Effect & Boot SE & Boot LLCI & Boot ULCI \\
\hline Model I & PA & 0.049 & 0.030 & -0.003 & 0.114 \\
Model II & PA & 0.056 & 0.034 & -0.008 & 0.126 \\
Model III & PA & 0.126 & 0.038 & 0.063 & 0.212 \\
\hline
\end{tabular}

Coefficient of Correlation is 0.471 , which states that self-confidence and positive attitude have moderate relationship with need for achievement. Coefficient of determination is 0.221 , which means that $22.10 \%$ of the model is explained by independent variables (Table 1, Model I).

In the first case, the significance value is 0.057 , which is more than 0.05 , so there is no relationship between positive attitude and innovativeness. In the second case, the significance value is 0.000 , so there is a relationship between self-confidence and innovativeness (Table 2, Model II).

The hypothesis that positive attitude mediates that the positive relationship between self-confidence and need for achievement has been rejected. Because the lower limit of confidence interval is -0.008 and the upper limit of confidence interval is 0.126 , zero lies between the upper and lower limit of confidence interval (Table 3, Model II).

Coefficient of Correlation is 0.522 , which states that self-confidence and positive attitude have moderate relationship with motivation. Coefficient of determination is 0.272 , which means that $27.23 \%$ of the model is explained by independent variables (Table 1, Model III).

In the first case, the significance value is 0.000 , so there is a relationship between positive attitude and motivation. In the second case, the significance value is 0.000 , so there is a relationship between self-confidence and motivation (Table 2, Model III). The hypothesis that positive attitude mediates the positive relationship between self-confidence and motivation has been accepted because the lower limit of confidence interval is 0.063 and the upper limit of confidence interval is 0.212 , thus both values are positive and zero does not lie in between the upper and lower limit of confidence interval (Table 3 , Model III).

The probability of getting a critical ratio as large as 3.023 in absolute value is 0.003 . In other words, the regression weight for locus of control through entrepreneurship education in the prediction of 
innovativeness in university students is significantly different from zero at the 0.01 level (two-tailed). The probability of getting a critical ratio as large as 4.509 in absolute value is less than 0.001 . In other words, the regression weight for locus of control through entrepreneurship education in the prediction of need for achievement in university students is significantly different from zero at the 0.001 level (two-tailed). The probability of getting a critical ratio as large as 4.658 in absolute value is less than 0.001. In other words, the regression weight for locus of control through entrepreneurship education in the prediction of motivation in university students is significantly different from zero at the 0.001 level (two-tailed) (Table 4, Model I).

Table 4. Regression Weights.

\begin{tabular}{ccccccccc}
\hline & & & & Estimate & S.E. & C.R. & $p$ & Label \\
\hline \multirow{4}{*}{ Model I } & Inn & $<-$ & LC & 0.160 & 0.053 & 3.023 & 0.003 & par_4 \\
& NFA & $<-$ & LC & 0.240 & 0.053 & 4.509 & 0.000 & par_5 \\
& Mot & $<-$ & LC & 0.227 & 0.049 & 4.658 & 0.000 & par_6 \\
\hline \multirow{3}{*}{ Model II } & Inn & $<-$ & RTP & 0.217 & 0.053 & 4.076 & 0.000 & par_4 \\
& NFA & $<-$ & RTP & 0.226 & 0.055 & 4.127 & 0.000 & par_5 \\
& Mot & $<-$ & RTP & 0.286 & 0.049 & 5.874 & 0.000 & par_6 \\
\hline
\end{tabular}

When locus of control through entrepreneurship goes up by 1 standard deviation, innovativeness in university students goes up by 0.188 standard deviations. When locus of control through entrepreneurship goes up by 1 standard deviation, need for achievement in university students goes up by 0.275 standard deviations. When locus of control through entrepreneurship goes up by 1 standard deviation, motivation in university students goes up by 0.283 standard deviations (Table 5 , Model I).

Table 5. Standardized Regression Weights.

\begin{tabular}{ccccc}
\hline \multirow{4}{*}{ Model I } & & & & Estimate \\
& Inn & $<-$ & LC & 0.188 \\
& NFA & $<-$ & LC & 0.275 \\
& Mot & $<-$ & LC & 0.283 \\
\hline \multirow{4}{*}{ Model II } & Inn & $<-$ & RTP & 0.250 \\
& NFA & $<-$ & RTP & 0.253 \\
& Mot & $<-$ & RTP & 0.349 \\
\hline
\end{tabular}

The probability of getting a critical ratio as large as 4.076 in absolute value is less than 0.001 . In other words, the regression weight for risk taking propensity in university students in the prediction of innovativeness in university students is significantly different from zero at the 0.001 level (two-tailed). The probability of getting a critical ratio as large as 4.127 in absolute value is less than 0.001 . In other words, the regression weight for risk taking propensity in university students in the prediction of need for achievement in university students is significantly different from zero at the 0.001 level (two-tailed). The probability of getting a critical ratio as large as 5.874 in absolute value is less than 0.001 . In other words, the regression weight for risk taking propensity in university students in the prediction of motivation in university students is significantly different from zero at the 0.001 level (two-tailed) (Table 4, Model II).

When risk taking propensity in university students goes up by 1 standard deviation, innovativeness in university students goes up by 0.25 standard deviations. When risk taking propensity in university students goes up by 1 standard deviation, need for achievement in university students goes up by 0.253 standard deviations. When risk taking propensity in university students goes up by 1 standard deviation, motivation in university students goes up by 0.349 standard deviations (Table 5 , Model II). 
Coefficient of Correlation is 0.522 , which states that self-confidence, fortitude and interaction effect have moderate relationships with student's motivation level. Coefficient of Determination is 0.273 , which means that $27.30 \%$ of the model is explained by independent variables (Table 6 , Model I).

Table 6. Model Summary (Testing Hypothesis H4a-c).

\begin{tabular}{cccccccc}
\hline & R & R-seq & MSE & F & df1 & df2 & $p$ \\
\hline Model I & 0.522 & 0.273 & 0.410 & 30.712 & 3 & 246 & 0.000 \\
Model II & 0.419 & 0.176 & 0.465 & 18.987 & 3 & 246 & 0.000 \\
Model III & 0.402 & 0.162 & 0.473 & 15.834 & 3 & 246 & 0.000 \\
\hline
\end{tabular}

The moderation effect has been shown by "int_1" (i.e., SC X FOR), the $p$-value is 0.925 , which is more than 0.05 , so fortitude does not act as a moderator between self-confidence through entrepreneurship education and motivation level of students (Table 7, Model I).

Table 7. Model (Testing Hypothesis H4a-c).

\begin{tabular}{|c|c|c|c|c|c|c|c|}
\hline \multirow{6}{*}{ Model I } & & Coeff & Se & $\mathbf{T}$ & $p$ & LLCI & ULCI \\
\hline & constant & 1.943 & 2.564 & 0.758 & 0.449 & -3.107 & 6.994 \\
\hline & For & 0.248 & 0.427 & 0.581 & 0.562 & -0.593 & 1.088 \\
\hline & SC & 0.351 & 0.454 & 0.772 & 0.441 & -0.544 & 1.245 \\
\hline & int_1 & 0.007 & 0.075 & 0.094 & 0.925 & -0.141 & 0.155 \\
\hline & \multicolumn{7}{|c|}{ Interactions: int_1 = SC X For } \\
\hline \multirow{6}{*}{ Model II } & & Coeff & Se & $\mathbf{T}$ & $p$ & LLCI & ULCI \\
\hline & constant & 5.681 & 0.047 & 120.157 & 0.000 & 5.588 & 5.774 \\
\hline & For & 0.355 & 0.070 & 5.038 & 0.000 & 0.216 & 0.493 \\
\hline & $\mathrm{LC}$ & 0.174 & 0.055 & 3.184 & 0.002 & 0.066 & 0.282 \\
\hline & int_1 & 0.218 & 0.074 & 2.925 & 0.004 & 0.071 & 0.364 \\
\hline & \multicolumn{7}{|c|}{ Interactions: int_1 = LC X For } \\
\hline \multirow{6}{*}{ Model III } & & Coeff & Se & $\mathrm{T}$ & $p$ & LLCI & ULCI \\
\hline & Constant & 4.382 & 2.342 & 1.871 & 0.063 & -0.231 & 8.995 \\
\hline & For & 0.064 & 0.386 & 0.165 & 0.869 & -0.696 & 0.823 \\
\hline & RTP & -0.154 & 0.445 & -0.346 & 0.730 & -1.031 & 0.723 \\
\hline & int_1 & 0.055 & 0.073 & 0.758 & 0.449 & -0.088 & 0.199 \\
\hline & \multicolumn{7}{|c|}{ Interactions: int_1 = RTP X For } \\
\hline
\end{tabular}

When there is low fortitude and low Self-confidence, motivation level of student is low, and, when self-confidence is high but fortitude is low, motivation is high. When fortitude is high and self-confidence is low, motivation level of students is low but, with high self-confidence and high fortitude, motivation is also high. Thus, fortitude does not act as moderator between self-confidence and motivation level of students (Figure 4).

Coefficient of Correlation is 0.419 , which states that locus of control, fortitude and interaction effect have moderate relationships with motivation level of students. Coefficient of Determination is 0.176 , which means that $17.60 \%$ of the model is explained by independent variables (Table 6, Model II).

In first case, the significance value is 0.000 , so there is a relationship between fortitude and motivation. In the second case, the significance value is 0.002 , so there is a relationship between locus of control and motivation. The moderation effect has been shown by "int_1" (i.e., LC X For), the $p$-value is 0.004 , which is again less than 0.05 , so fortitude acts as a moderator between locus of control and motivation (Table 7, Model II). 


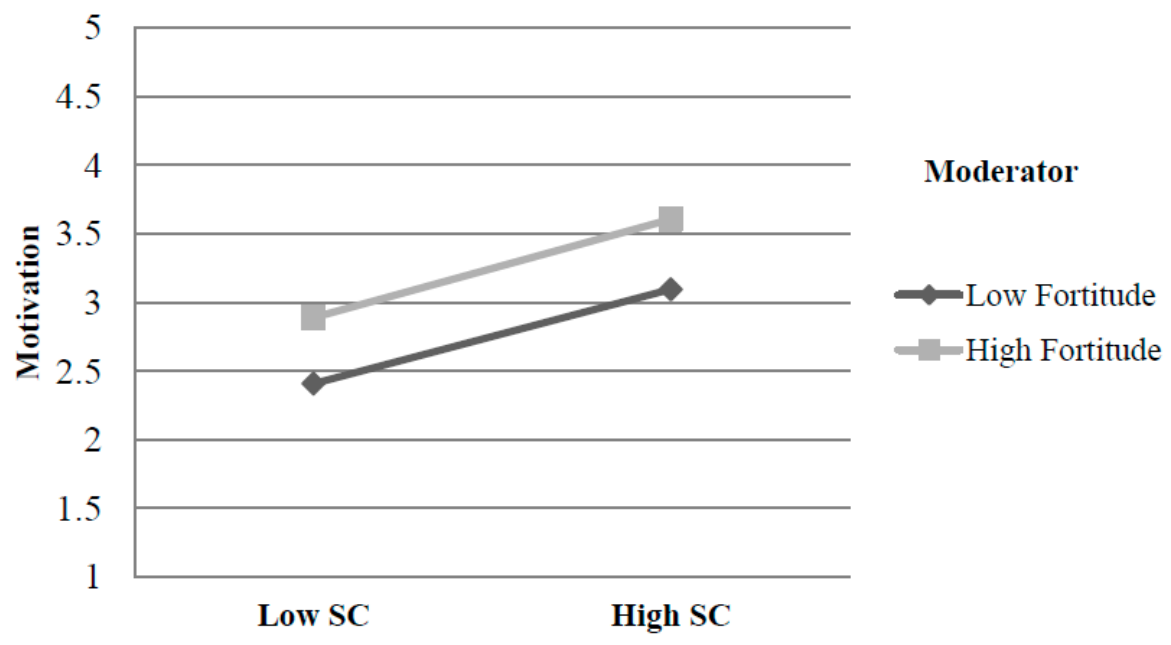

Figure 4. Interaction effect (Hypothesis H4a).

Standard deviation below the mean is -0.666 , the mean value is 0.000 , and above the mean is 0.666. For low levels of fortitude, the effect size is 0.029 , which is insignificant; for medium fortitude level, effect size is 0.174 , which is significant; and for high levels of fortitude, the effect size is 0.319 , which is even more significant. Thus, as we move from low levels to high levels of fortitude, the effect size increases and it even becomes more significant (Table 8).

Table 8. Conditional effect of X on Y (Testing Hypothesis H4b).

\begin{tabular}{ccccccc}
\hline For & Effect & Se & T & $p$ & LLCI & ULCI \\
\hline-0.666 & 0.029 & 0.057 & 0.516 & 0.606 & -0.082 & 0.140 \\
0 & 0.174 & 0.055 & 3.184 & 0.002 & 0.066 & 0.282 \\
0.666 & 0.319 & 0.088 & 3.635 & 0.000 & 0.146 & 0.492 \\
\hline
\end{tabular}

When there is low fortitude and low locus of control, motivation is also low, and, when locus of control is high but fortitude is low, motivation is still low, which shows that with fortitude there is a positive result. When fortitude is high and locus of control is low, motivation is low but, when locus of control is high and fortitude is high, motivation is also high. Thus, fortitude strengthens the positive relationship between locus of control and motivation (Figure 5).

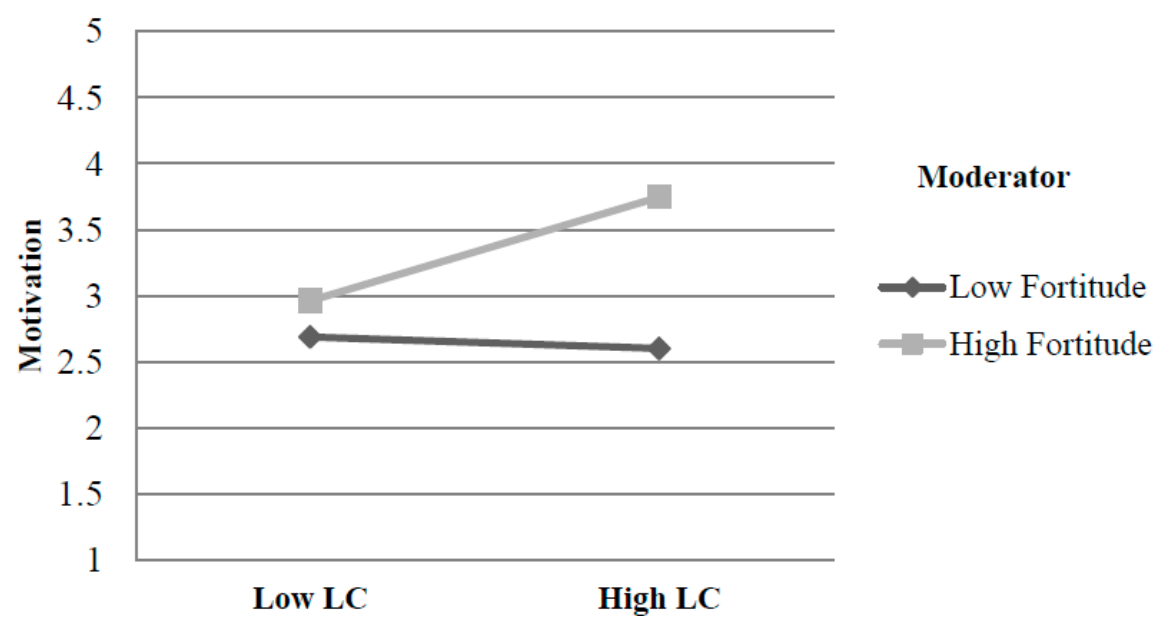

Figure 5. Interaction effect (Hypothesis H4b). 
Coefficient of Correlation is 0.402 , which states that self-confidence, fortitude and interaction effect have moderate relationships with MOT. Coefficient of determination is 0.162 , which means that $16.20 \%$ of the model is explained by independent variables (Table 6, Model III).

The moderation effect has been shown by "int_1" (i.e., RTP X For), the $p$-value is 0.449 , which is more than 0.05 , so fortitude does not act as a moderator between risk taking propensity and motivation (Table 7, Model III).

When there is low fortitude and low risk taking propensity, motivation is high, and, when risk taking propensity is high but fortitude is low, need for achievement is low. When fortitude is high and risk taking propensity is low, motivation is high but, when risk taking propensity is high and fortitude is high, motivation is low. Thus, fortitude does not act as moderator between risk taking propensity and motivation (Figure 6).

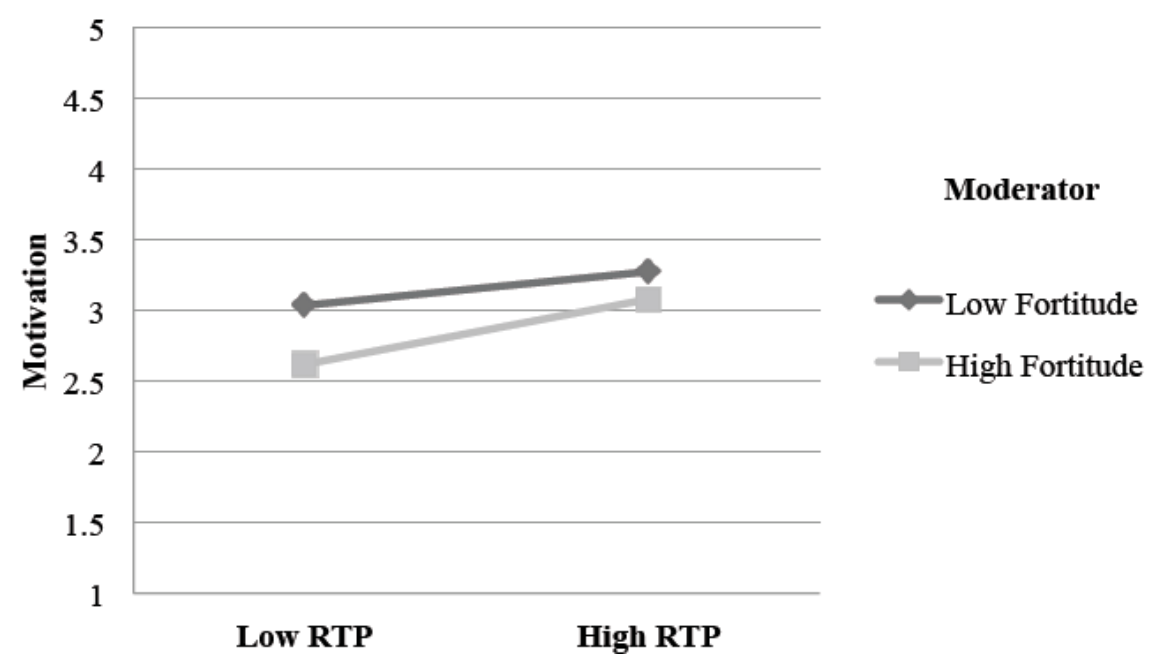

Figure 6. Interaction effect (Hypothesis $\mathrm{H} 4 \mathrm{c}$ ).

\section{Conclusions}

The study provides valuable insight into how necessary skills can be inculcated in university students so that they might contribute towards the sustainable development of the country. It was hypothesized that entrepreneurship education evokes self-confidence, locus of control and risk taking propensity in university students. These three predictors lead a student on the path of entrepreneurship by developing skills identified by entrepreneurship theories, namely innovation, need for achievement, and motivation. The data did not support any effect of positive attitude as mediator of self-confidence on innovation and need for achievement; however, it has been established that students with self-confidence through entrepreneurship education will have positive attitude and will be more motivated.

Results also highlighted that internal locus of control and risk taking propensity through entrepreneurship education generates innovation, need for achievement, and motivation in university students. Hence, these two predictors significantly contribute to the entrepreneurship theories mentioned in the literature review section.

Furthermore, it was also shown that students high in fortitude will be more motivated by entrepreneurship education. This was not, however, proven for self-confidence and risk taking propensity. Interaction effect of fortitude has been fully supported for internal locus of control and motivation. Thus, students that have high internal locus of control will be more motivated with high fortitude, while they will be less motivated with lower levels of fortitude. 


\section{Discussion}

This paper discusses about the relationship of entrepreneurship intention produced by human capital obtained through academic journey. In our literature, we have discussed formal and informal education and its consequences on entrepreneurial intention.

A similar study was conducted by Collins et al. [59], and the findings were similar. Both studies investigated the correlation between need for achievement and entrepreneurial potential in young adults.

Global Entrepreneurship Monitor reported recently that to support small and medium sized enterprises in GCC a wide array of business ideas should be encouraged. Support of government with entrepreneur education creates an educated work force, resulting in innovation, high productivity and strengthened economy [64].

Moreover, we have also contributed to the literature by developing and testing the theory of Innovation by Schumpeter [71], Learned Need Theory proposed by McClelland [72] and Atkinson [73], achievement success theory, taking Fortitude as moderator and gauged the impact of locus of control, risk taking propensity and self-confidence on said theories.

Thus, our research gives a direction to academicians and policy makers to give consolidation of formal and informal education that support graduates to be good entrepreneurs. In GCC countries, information and communication technology based education is already practiced [113], so it will very helpful to enhance students skills to be good entrepreneur, by teaching them in an academic realm where both types of education are practiced. All previous research was based on either formal or informal education, but, in our research, we have established that informal education's variables mediated with formal education's variable has a strongly positive impact on shaping entrepreneurial qualities in a graduate. To enhance the National educational system of GCC, both formal and informal sustainable educational practices are needed. Reassessment of entrepreneur courses in academics is needed to augment the production of potential graduates. We believe it will help produce analytical and problem solving skills with ability to design systems and independent thinking capabilities.

\section{Limitations}

Some limitations associated with the present study include the following.

First, the sample selected was gathered from a single public sector university, which limits the generalization. In the future, we recommend collection of data from multiple universities, both public and private. There were few demographic variables and the sample was male dominated and a narrow age group.

Second, as per the US Department of State, the religious demography of UAE consists of $87 \%$ Muslim citizens. Thus, the impact of this religious demography was that the majority of the samples were Muslims and it is part of their belief that doing your own business has 70 times more divine blessings then doing a job. Therefore, the true spirit of Entrepreneurship was primarily influenced by their belief rather than the Entrepreneurial drive.

Third, this research paper discusses the theories of Entrepreneurship and attitudinal changes that may occur because of Entrepreneurship education. We can further study the role of Digital age on businesses. Therefore, role of Technology Acceptance Model can also be included to further study the effect of technology acceptance on Sustainable Entrepreneurship.

Fourth, in this research, we have selected the sample from students who have already completed the entrepreneurship course. The study can be made more rigorous by collecting data from the students before studying entrepreneurship and then their responses can be compared and change can be noted after completion of entrepreneurship course. 


\section{Reforms to Enhance Science, Technology, and Innovation in UAE}

Having an expert analysis of the educational system of UAE, it is necessary to embark on some beneficial reforms in educational development to obtain the highest amount of productivity in entrepreneur graduates. Many studies have contributed positively into the knowledge about entrepreneurship, but still there is much more to investigate to explore the new avenues about the entrepreneurial education in Higher Education Institutes (HEIs) and Degree Awarding institutions (DAIs) specifically in UAE.

There is a need to formulate the holistic approach to promote entrepreneurship education, thus we propose that government should partially fund initial level small projects at school, college and university levels to encourage students to take risk for the enhancement of risk taking propensity. This initial level funding may give students an experience to overcome the fear of failure and to enjoy success. If a student becomes successful, government may take that business to next level such as other areas of UAE or GCC and if it is a failure at least the student may have experience to face the fear of failure-as failure is the first step towards success. This will make it easy to minimize the distances in strategies and ensure the outreach, thus it will lead towards higher impact to encourage entrepreneurship in youth.

An entrepreneur from the industry can form a real world adjunct classroom specifically in entrepreneurial education. The important learning outcomes are not just that guest speakers share practical knowledge and experience but student opinion may also change by seeing a successful entrepreneur. Moreover, students may idealize them and get inspiration from the very start of their schooling so their behavior will be influenced to be one of their ideal entrepreneur personalities.

We propose that the education ministry should promote the entrepreneurial education at various levels starting from schools to higher education, success stories of local and young entrepreneurs should be made a part of the curriculum, so that the cognitive behavior of students may be influenced to become entrepreneurs. Introducing the facility of career counseling in various academic levels with competent career counselors can give them direction to become a successful entrepreneur.

Both students and practitioners should know how to maximize profitability by utilizing lean resources, specifically in countries where socio economic situation is not overwhelming for new startups. We also propose that the Government should introduce how lean entrepreneurship may start new social economic lifecycle in the UAE because of recent fluctuating economic situation where oil prices are dynamic and declining over the last five years. Online portal for all the academic institutions may be established from where students can take advantage of available resources and real life stories and examples of existing entrepreneurs and businesses.

Acknowledgments: This research was supported by the R\&D department of Iqra University, Karachi. Thanks to all who contributed in the data collection.

Author Contributions: Irfan Hameed presented the idea and wrote the first draft of this paper. Muhammad Babar Khan revised the first draft. Atif Shahab was involved in the literature review along with Irfan Hameed and Muhammad Babar Khan. Data analysis was done by the joint effort of Imran Hameed and Faisal Qadeer. Finally, all authors revised, discussed and approved the manuscript.

Conflicts of Interest: The authors do not have any conflict of interest.

\section{References}

1. Hall, J.K.; Martin, M.J.C. Disruptive technologies, stakeholders and the innovation value-added chain: A framework for evaluating radical technology development. RED Manag. 2005, 35, 273-284.

2. Hallami, M.O.; Horne, C.; Huang, V.Z. Technological Innovation in the United Arab Emirates: Process and Challenges. Trans. Corp. Rev. 2013, 5, 46-59.

3. United Nations. The World Investment Report, Transnational Corporations and the Internationalization of RED; United Nation Publication: Geneva, Switzerland, 2005.

4. Dutot, V.; van Horne, C. Digital Entrepreneurship Intention in a Developed vs. Emerging Country: An Exploratory Study in France and the UAE. Trans. Corp. Rev. 2015, 7, 79-96. [CrossRef] 
5. Tarbush, S. Strength in Knowledge-MENA Acceleration Research, Development and Innovation; Global Arab Network: Dubai, UAE, 2010.

6. Mubadala. Patent Application No. PCT/IB2008/000438. 2010. Available online: http://mubadala.ae (accessed on 14 June 2016).

7. Emirates News Agency. Scientific Research Budget in Government Universities Is Low; WAM: Abu Dhabi, UAE, 2010.

8. Van Horne, C.; Huang, V.; Al Awad, M. UAE GEM Report 2011; Zayed University: Abu Dhabi, UAE, 2012.

9. Souitaris, V.; Zerbinati, S.; Al-Laham, A. Do entrepreneurship programmes raise entrepreneurial intention of science and engineering students? The effect of learning, inspiration and resources. J. Bus. Ventur. 2007, 22, 566-591. [CrossRef]

10. Zhang, Y.; Duysters, G.; Cloodt, M. The role of entrepreneurship education as a predictor of university students' entrepreneurial intention. Int. Entrep. Manag. J. 2014, 10, 623-641. [CrossRef]

11. Hamzah, H.; Yahya, Z.; Sarip, A.G.; Adnan, Y.M. Impact of entrepreneurship education programme (EEP) on entrepreneurial intention of real estate graduates. Pac. Rim Prop. Res. J. 2016, 22, 17-29. [CrossRef]

12. Kao, J.J. The Entrepreneurial Organization; Prentice Hall: Upper Saddle River, NJ, USA, 1991.

13. Ibrahim, A.B.; Soufani, K. Entrepreneurship education and training in Canada: A critical assessment. Educ. Train. 2002, 44, 421-430. [CrossRef]

14. Majumdar, S.; Varadarajan, D. Students' attitude towards entrepreneurship: Does gender matter in the UAE? Foresight 2013, 15, 278-293. [CrossRef]

15. Wang, C.K.; Wong, P. Entrepreneurial interest of university students in Singapore. Technovation 2004, 24, 163-172. [CrossRef]

16. Turker, D.; Selcuk, S.S. Which factors affect entrepreneurial intention of university students? J. Eur. Ind. Train. 2009, 33, 142-159. [CrossRef]

17. Oosterbeek, H.; van Praag, M.; Ijsselstein, A. The impact of entrepreneurship education on entrepreneurship skills and motivation. Eur. Econ. Rev. 2010, 54, 442-454. [CrossRef]

18. Von Graevenitz, G.; Harhoff, D.; Weber, R. The effects of entrepreneurship education. J. Econ. Behav. Organ. 2010, 76, 90-112. [CrossRef]

19. Quality Assurance Agency. Enterprise and Entrepreneurship Education: Guidance for UK Higher Education Providers. Quality Assurance Agency for Higher Education. 2012. Available online: http://www.qaa.ac.uk/ en/Publications/Documents/enterprise-entrepreneurship-guidance.pdf (accessed on 14 July 2016).

20. The Abu Dhabi Economic Vision 2030. Available online: https://www.ecouncil.ae/PublicationsEn/ economic-vision-2030-full-versionEn.pdf (accessed on 1 August 2016).

21. Nicola, M. Middle East: The Rising Importance of SMEs (Special Report Standard Chartered Bank). 2009. Available online: http:/ / research.standardchartered.com (accessed on 7 August 2016).

22. Baumol, W. The Free-Market Innovation Machine: Analyzing the Growth Miracle of Capitalism; Princeton University Press: Princeton, NJ, USA, 2002.

23. Van Stel, A.J. Empirical Analysis of Entrepreneurship and Economic Growth; Springer: New York, NY, USA, 2006.

24. Wennekers, S.; van Stel, A.J.; Thurik, R.; Reynolds, P.D. Nascent entrepreneurship and the level of economic development. Small Bus. Econ. 2005, 24, 293-309. [CrossRef]

25. Al Nowais, S. Education System to Get Overhaul. Gulf News On-Line. Available online: http://www. gulfnews.com/Articles/print2.asp?ArticleID=141170 (accessed on 10 August 2016).

26. Ferris-Lay, C. UAE Schools Failing to Equip Pupils for Workplace. Arabian Business News. Available online: http:/ /www.arabianbusiness.com/uae-schools-failingequip-pupils-for-workplace-360042.html (accessed on 10 August 2016).

27. Godwin, L.N.; Stevens, C.E.; Brenner, N.L. Forced to play by the rules? Theorizing how mixed sex founding teams benefit women entrepreneurs in male-dominated contexts. Entrep. Theory Pract. 2006, 30, 623-643. [CrossRef]

28. McCrohan, D.; Erogul, M.S.; Vellinga, N.; Tong, Q. Global Entrepreneurship Monitor, National Report, United Arab Emirates 2009; College of Business Sciences, Zayed University: Abu Dhabi, UAE, 2009.

29. Duncan, G.; Parmer, N. Problems Facing Entrepreneurs and SMEs in the UAE. The National. 2011. Available online: http:/ / www.thenational.ae/thenationalconversation/industry-insights/finance/problems-facingentrepreneurs-and-smes-in-the-uae (accessed on 13 August 2016). 
30. Mahfouz, E. Tadros. The Arab Gulf States and the Knowledge Economy: Challenges and Opportunities. Available online: http://www.agsiw.org/wp-content/uploads/2015/07/Tadros_Knowledge-Economy_ Rev1.pdf (accessed on 13 August 2016).

31. Ali, M. Al-Khouri Digital identity: Transforming GCC economies. Innovation 2014, 16, 184-194.

32. Morris, M.H.; Davis, D.L.; Allen, J.W. Fostering corporate entrepreneurship: Cross-cultural comparisons of the importance of individualism versus collectivism. J. Int. Bus. Stud. 1994, 25, 65-89. [CrossRef]

33. Hofstede, G. Cultures and Organizations. Software of the Mind: Intercultural Cooperation and Its Importance for Survival; Harper Collins: London, UK, 1994.

34. Morris, M.H.; Avila, R.A.; Allen, J.W. Individualism and the modern corporation: Implications for innovation and entrepreneurship. J. Manag. 1993, 19, 595-612. [CrossRef]

35. El-Gohary, H.; O'Leary, S.; Radway, P. Investigating the Impact of Entrepreneurship Online Teaching on Science and Technology Degrees on Students attitudes in Developing Economies: The case of Egypt. Int. J. Online Mark. 2012, 2, 29-45. [CrossRef]

36. International Entrepreneurship Educators Programme: Economic Impact Potential, Report for National Council of Graduate Entrepreneurship. 2010. Available online: http://www.ncge.org.uk/publication/ ieepreport.pdf (accessed on 15 August 2016).

37. Shaw, K.E. Higher Education in the Gulf: Problems and Prospects; University of Exeter Press: Exeter, UK, 1997.

38. Ministry of Higher Education in the United Arab Emirates 2016 Strategic Goals. Available online: https: //www.mohesr.gov.ae/En/AboutTheMinistry/Pages/StrategicGoals.aspx (accessed on 10 August 2016).

39. Wiseman, A.W.; Alromi, N.H. The Employability Imperative: Schooling for Work as a National Project; Nova Science Publishers: Hauppauge, NY, USA, 2007.

40. Kautonen, T.; van Gelderen, M.; Fink, M. Robustness of the theory of planned behaviour in predicting entrepreneurial intentions and action. Entrep. Theory Pract. 2015, 39, 655-674. [CrossRef]

41. Davey, T.; Plewa, C.; Struwig, M. Entrepreneurship perceptions and career intentions of international students. Educ. Train. 2011, 53, 335-352. [CrossRef]

42. Hattab, T.; Albouy, C.; Lasram, F.B.R.; Somot, S.; Le Loc'h, F.; Leprieur, F. Towards a better understanding of potential impacts of climate change on marine species distribution: A multi scale modelling approach. Glob. Ecol. Biogeogr. 2014, 23, 1417-1429. [CrossRef]

43. Hashim, M.K. Small and Medium-Sized Enterprises in Malaysia Role and Issues; University Utara Malaysia Press: Sintok, Malaysia, 2002; ISBN: 9832479231.

44. Armanurah, M.; Abdul Razak, A.; Syahrina, A. Kepentingan pendidikan keusahawanan kepada organisasi dan Negara. In Proceedings of the National Conference on Skills and Competencies in Education, Selangor, Malaysia, 2012; pp. 101-106. (In Malayan)

45. Mahmood, R.; Foster, S.A.; Logan, D. The GeoProfile metadata, exposure of instruments, and measurement bias in climatic record revisited. Int. J. Climatol. 2010, 26, 1091-1124. [CrossRef]

46. Solomon, D.; Fritzsche, F.; Tekalign, M.; Lehmann, J.; Zech, W. Soil organic matter composition in the sub-humid Ethiopian highlands as influenced by deforestation and agricultural management. Soil Sci. Soc. Am. J. 2002, 66, 68-82. [CrossRef]

47. Katz, J.A. The chronology and intellectual trajectory of American entrepreneurship education 1876-1999. J. Bus. Ventur. 2003, 18, 283-300. [CrossRef]

48. Sánchez, J.C. The impact of an entrepreneurship education program on entrepreneurial competencies and intention. J. Small Bus. Manag. 2013, 51, 447-465. [CrossRef]

49. Huber, L.R.; Sloof, R.; van Praag, M. The effect of early entrepreneurship education: Evidence from a field experiment. Eur. Econ. Rev. 2014, 72, 76-97. [CrossRef]

50. Mitra, J.; Manimala, J.M. Higher education's role in entrepreneurship and economic development. Local Econ. Employ. Dev. 2008. [CrossRef]

51. Yeng Kiat, O.; Shuhymee, A. A study among university students in business start-ups in Malaysia: Motivations and obstacles to become entrepreneurs. Int. J. Bus. Soc. Sci. 2012, 3, 181-192.

52. Zuhairah, A.A.G.; Herna, M.; Zarinah, H. Legal eagle entrepreneurship education for law students: Special reference to International Islamic University Malaysia. Pertan. J. Soc. Hum. 2014, 22, 83-98. 
53. Berma, M.; Shamshubaridah, R.; Faridah, S.; Shazlinda, M.Y. Developing an entrepreneurship education eco-system at University Kebangsaan Malaysia (UKM): A critical analysis on teaching, learning and knowledge development. In Proceedings of the Teaching and Learning Convention, Selangor, Malaysia, 2012; pp. 1-36.

54. Malaysia Qualification Register (MQR). Search for Qualifications Public Government Institutions; Malaysian Qualifications Agency: Selangor, Malaysia, 2009.

55. Ministry of Higher Education in the United Arab Emirates (2016a). Guide on Higher Education in the United Arab Emirates in the Academic Year 2013/2014. Available online: http:/ / www.mohesr.gov.ae/En/ ServicesIndex/Documents/UAE-factbook24Feb-en-CDversion.pdf (accessed on 5 August 2016).

56. Pittaway, L.; Cope, J. Entrepreneurship Education: A Systematic Review of the Evidence. Int. Small Bus. J. 2007, 25, 479-510. [CrossRef]

57. GEM Report on Entrepreneurship in the United Arab Emirates. Available online: http://www. gemconsortium.org/country-profile/130 (accessed on 6 August 2016).

58. Van Praag, C.M. Successful Entrepreneurship; Edward Elgar: Cheltenham, UK, 2005.

59. Collins, L.; Hannon, P.D.; Smith, A. Enacting entrepreneurial intent: The gap between students' needs and higher education capabilities. Educ. Train. 2004, 48, 454-463. [CrossRef]

60. Syahrina, A.; Armanurah, M.; Habshah, B.; Norashidah, H.; YengKiat, O. Tracer study of bachelor in entrepreneurship program: The case of Universiti Utara Malaysia. Int. J. Educ. Res. 2013, 1, 1-10.

61. Millán, J.M.; Congregado, E.; Román, C.; van Praag, M.; van Stel, A. The value of an educated population for an individual's entrepreneurship success. J. Bus. Ventur. 2013, 29, 612-632. [CrossRef]

62. Becker, G. Human Capital: A Theoretical and Empirical Analysis with Special Reference to Education, 3rd ed.; University of Chicago Press: Chicago, IL, USA, 1964.

63. Mincer, J. Investment in human capital and personal income distribution. J. Political Econ. 1958, 66, $281-302$. [CrossRef]

64. Gennaioli, N.; La Porta, R.; Lopez-de-Silanes, F.; Shleifer, A. Human capital and regional development. Q. J. Econ. 2013, 128, 105-164. [CrossRef]

65. Schlaegel, C.; Koenig, M. Determinants of entrepreneurial intent: A meta-analytic test and integration of competing models. Enterp. Theory Pract. 2014, 38, 291-332. [CrossRef]

66. Rauch, A.J.; Hulsink, W. Putting entrepreneurship education where the intention to act lies. An Investigation into the Impact of Entrepreneurship Education on Entrepreneurial Behaviour. Acad. Manag. Learn. Educ. 2015, 14, 1-18. [CrossRef]

67. Muhammad, A.; Akbar, S.; Dalziel, M. The journey to develop educated entrepreneurs: Prospects and problems of Afghan businessmen. Educ. Train. 2011, 53, 433-447. [CrossRef]

68. ZainalAbidin, M.; Golnaz, R.I.; Amin, M.A.; Ezhar, T. Work culture and developing agri-entrepreneurial skills among farmers. Am. J. Econ. Bus. Admin. 2011, 3, 490-497.

69. Grilo, I.; Irigoyen, J.M. Entrepreneurship in the EU: To wish and not to be. Small Bus. Econ. 2006, 26, 305-318. [CrossRef]

70. The American Dream. Available online: http://www.loc.gov/teachers/classroommaterials/lessons/ american-dream/students/thedream.html (accessed on 21 July 2016).

71. Sweezy, P.M. Professor Schumpeter's theory of innovation. In The Review of Economic Statistics; The MIT Press: Cambridge, MA, USA, 1943; pp. 93-96.

72. McClelland, C.A. The acute international crisis. World Politics 1961, 14, 182-204. [CrossRef]

73. Atkinson, R.C.; Shiffrin, R.M. Human memory: A proposed system and its control processes. Psychol. Learn. Motiv. 1968, 2, 89-195.

74. Shelly, A.B.; Seung, Y.C. Factors that influence informal learning in the workplace. J. Workplace Learn. 2008, 20, 229-244.

75. Dean, T.J.; McMullen, J.S. Toward a theory of sustainable entrepreneurship: Reducing environmental degradation through entrepreneurial action. J. Bus. Ventur. 2007, 22, 50-76. [CrossRef]

76. Kogan, N.; Wallach, M.A. Certainty of judgment and the evaluation of risk. Psychol. Rep. 1960, 6, $207-213$. [CrossRef]

77. Agarwal, R.; Prasad, J. A Conceptual and Operational Definition of Personal Innovativeness in the Domain of Information Technology. Inf. Syst. Res. 1998, 9, 204-215. [CrossRef] 
78. McMullan, W.E.; Long, W.A.; Wilson, A. MBA concentration on entrepreneurship. J. Small Bus. Entrep. 1985, 3, 18-22. [CrossRef]

79. Zimmerman, B.; Schunk, D.H. Handbook of Self-Regulation of Learning and Performance; Taylor \& Francis: New York, NY, USA, 2011.

80. Akerlind, G.S. Growing and developing as a university teacher-Variation in meaning. Stud. Higher Educ. 2003, 28, 375-390. [CrossRef]

81. Tavani, C.M.; Losh, S.C. Motivation, self-confidence and expectations as predictors of the academic performances among our high school students. Child Study J. 2003, 33, 141-151.

82. Krech, D.; Crutchfield, R.S. Theory and Problems of Social Psychology; MacGraw-Hill: New York, NY, USA, 1948.

83. Fuson, W.M. Attitudes: A note on the concept and its research consequences. Am. Sociol. Rev. 1942, 7 , 856-857.

84. Campbell, D.T. The indirect assessment of social attitudes. Psychol. Bull. 1950, 47, 15-38. [CrossRef]

85. Ajzen, I.; Timko, C.; White, J.B. Self-monitoring and the attitude-behavior relation. J. Pers. Soc. Psychol. 1982, 42, 426. [CrossRef]

86. Pretorius, T.B. Fortitude as Stress Resistance: Development and Validation of the Fortitude Questionnaire (FORQ); University of the Western Cape: Bellville, South Africa, 1998.

87. Hazan, C.; Shaver, P. Romantic love conceptualized as an attachment process. J. Pers. Soc. Psychol. 1987, 52, 511. [CrossRef] [PubMed]

88. Robertson, M.; Collins, A.; Medeira, N.; Slater, J. Barriers to start-up and their effect on aspirant entrepreneurs. Educ. Train. 2003, 45, 308-316. [CrossRef]

89. Pithers, R.T.; Soden, R. Critical thinking in education: A review. Educ. Res. 2000, 42, 237-249. [CrossRef]

90. Harvey, L.; Blackwell, A. Gender bias in incomes of art and design graduates. Ind. High. Educ. 1999, 13, 323-329.

91. Ihmeideh, F.M.; Al-Omari, A.A.; Al-Dababneh, K.A. Attitudes toward Communication Skills among Students'-Teachers' in Jordanian Public Universities. Aust. J. Teach. Educ. 2010, 35, 1-11. [CrossRef]

92. Rotter, J.B. Generalized expectancies for internal versus external control of reinforcement. Psychol. Monogr. 1966, 80, 1-28. [CrossRef] [PubMed]

93. Bateman, T.S.; Crant, J.M. The proactive component of organizational behavior: A measure and correlates. J. Organ. Behav. 1993, 14, 103-118. [CrossRef]

94. Spector, P.E. Behavior in organizations as a function of employee's locus of control. Psychol. Bull. 1982, 91, 482-497. [CrossRef]

95. Beck, J.S. Cognitive Therapy: Basics and Beyond; Guilford: New York, NU, USA, 1995.

96. Bandura, A. Psychology of chance encounters and life paths. Am. Psychol. 1982, 37, 747-755. [CrossRef]

97. Fritson, K.K. Impact of journaling on students' self-efficacy and locus of control. Insight 2008, 3, 75-83.

98. Entrialgo, M.; Fernanderz, E.; Vazquez, C.J. The effect of organizational context on SME's entrepreneurship: Some Spanish evidence. Small Bus. Econ. 2001, 16, 223-236. [CrossRef]

99. Thomas, A.S.; Mueller, S.L. A case for comparative entrepreneurship: Assessing the relevance of culture. J. Int. Bus. Stud. 2000, 31, 287-301. [CrossRef]

100. Erdem, A.; Kerman, K.; Meric, B.; Ozsoz, M. Methylene Blue as a Novel Electrochemical Hybridization Indicator. Electroanalysis 2001, 13, 219-223. [CrossRef]

101. Brockhaus, R.H. The psychology of entrepreneur. In Encyclopedia of Entrepreneurship; Kent, C.A., Sexton, D.L., Vesper, K.H., Eds.; Prentice Hall: Englewood Cliffs, NJ, USA, 1982; pp. 39-71.

102. Littunen, H. Entrepreneurship and the characteristics of the entrepreneurial personality. Int. J. Entrep. Behav. Res. 2000, 6, 295-310. [CrossRef]

103. Liles, P.R. Who Are the Entrepreneurs? MSU Bus. Top. 1974, 22, 5-14.

104. Pretorius, T.B.; Heyns, P.M. Fortitude as Stress-Resistance: Development and Validation of the Fortitude Questionnaire (FORQ); University of the Western Cape: Cape Town, South Africa, 2005.

105. Deniz, G.; Erten, G.; Kücüksezer, U.C.; Kocacik, D.; Karagiannidis, C.; Aktas, E.; Akdis, C.A.; Akdis, M. Regulatory NK cells suppress antigen-specific T cell responses. J. Immunol. 2008, 180, 850-857. [CrossRef] [PubMed]

106. Podsakoff, P.M.; MacKenzie, S.B.; Lee, J.Y.; Podsakoff, N.P. Common method biases in behavioral research: A critical review of the literature and recommended remedies. J. Appl. Psychol. 2003, 88, 879-903. [CrossRef] [PubMed] 
107. Rosenberg, M. Society and the Adolescent Self-Image; Princeton University Press: Princeton, NJ, USA, 1965.

108. Jackson, D.N. Jackson Personality Inventory Manual; Research Psychologists Press: Goshen, NY, USA, 1976.

109. Lam, T.C.M.; Klockaras, J. Anchor point effects on the equivalence of questionnaire items. J. Educ. Meas. 1982, 19, 317-322. [CrossRef]

110. Hurt, H.T.; Joseph, K.; Cook, C.D. Scales for the measurement of innovativeness. Hum. Commun. Res. 1977, 4, 58-65. [CrossRef]

111. Hermans, H.J.M. A Questionnaire Measure of Achievement Motivation. J. Appl. Psychol. 1970, 54, $353-363$. [CrossRef] [PubMed]

112. Pintrich, R.R.; DeGroot, E.V. Motivational and self-regulated learning components of classroom academic performance. J. Educ. Psychol. 1990, 82, 33-40. [CrossRef]

113. Wiseman, A.W.; Anderson, E. ICT-integrated education and national innovation systems in the Gulf Cooperation Council (GCC) countries. Comput. Educ. 2014, 59, 607-618. [CrossRef]

(C) 2016 by the authors; licensee MDPI, Basel, Switzerland. This article is an open access article distributed under the terms and conditions of the Creative Commons Attribution (CC-BY) license (http://creativecommons.org/licenses/by/4.0/). 